the addition of the latter likewise tending to popularise the work.

In his preface Dr. Elliot reiterates and emphasises the remarks made in the companion volume as to "the excessive and probably unwarranted multiplications of species and races (made easy by the too liberal application of the trinomial system) " of American mammals in general. Many of the forms, he adds, which have received separate names are separated on the evidence of comparative instead of distinctive characters. That is to say, their differences from other types are so slight as to be incapable of definition except by comparison with the latter, often, indeed, involving the necessity of placing specimens of each side by side. Consequently, in many instances specimens cannot be referred to their respective species or races without access to museums.

Perhaps it is rather unfortunate that the author did not see his way to go one stage further, and mention what species and races are entitled, in his opinion, to recognition. A step would then have been made towards the elimination of the forms named on insufficient distinctive characters. Nowadays it is the fashion to assign a distinct name to every recognisable form, however slight may be its point of difference; but some limit in this direction will apparently have to be imposed before long, unless zoology is to become an impossible science. In our opinion, one way of mitigating the difficulty is by using specific terms in a comparatively wide sense, thus leaving the subspecies, or races, to be recognised or not according to the discretion of the individual student.

Nomenclature is another point on which the author has a good deal to say, and he mentions that some of the name employed in the companion volume have been changed in the present work. He hopes, however, that as the result of such changes " a nomenclature that at least will approach stability may, in the distant future, be expected to be reached." Possibly it may--at the cost of rendering al the older standard works on zoology, palæontology, distribution, and scientific travel worse than useless-but a proposal like that of emending such a name as Odocoileus (in universal use among his naturalist countrymen) to Odontocœlus scarcely seems calculated to pave the way to such a happy millennium!

Among changes in nomenclature that we specially regret to see is the substitution of Agouti for Cœlogenys as the name of the paca, largely on the ground that the former is the popular title of a totally different group of rodents, for which reason we think its use in the scientific sense should be barred. It is also distressing to see the familiar

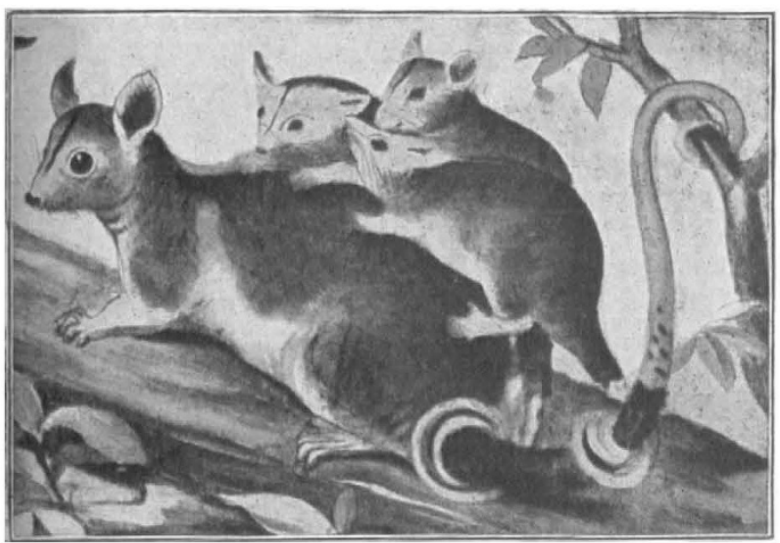

Fig. x.-Lord Derby's Opossum and young. From Elliot's " Mammals of Middle America."

name Hapale, for the marmosets, banished in favour of Callithrix, so long used for the titi monkeys, which now figure as Saimiri. On a par with the latter is the substitution of Tayassu for Dicotyles, of Coendu for Cercolabes, and of Potos for Cercoleptes, which is like an invasion of zoological Goths and Vandals into the sacred precincts of

NO. 1835 , VOL. $7 \mathrm{I}]$ classic Rome. One point in regard to the plan of the work -whether intentional or accidental it is not easy to saystrikes us as unsatisfactory. In the case of certain species, such as Odontocoelus americanus and Ovis cervina (pp. 69 and 84 ), for example, of which the typical form does not occur within the limits of the area under consideration,

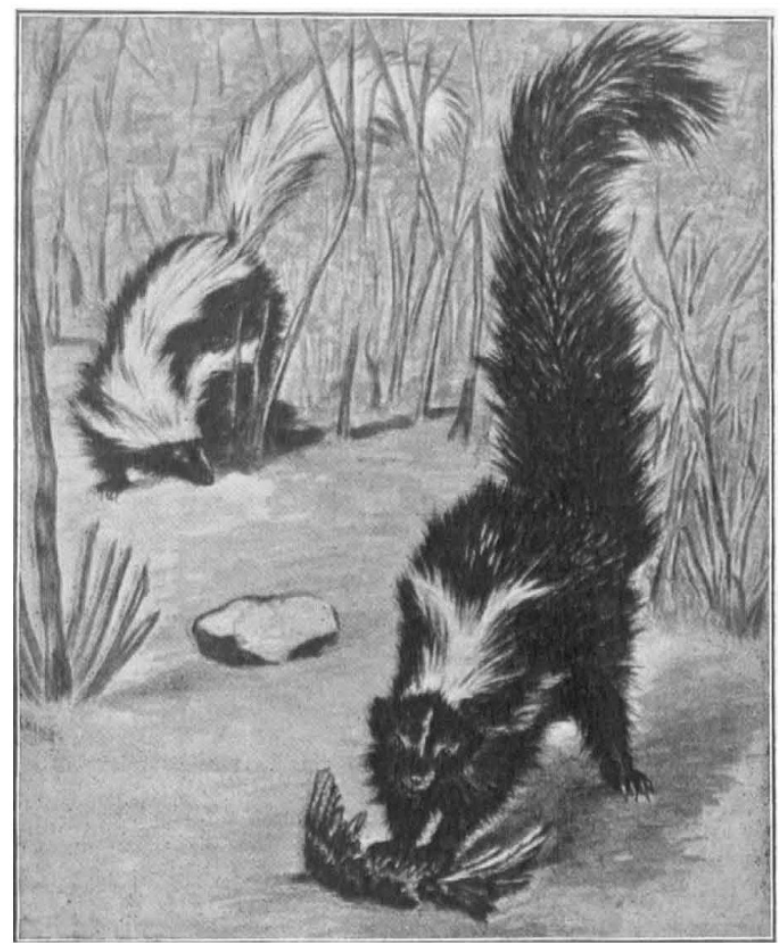
FIG. 2.-Long-tailed Skunk. From Elliot's "Mammals of Middle

the species-name itself does not appear in the list at all, but oniy the subspecies, such forms consequently lacking a distinctive number, and thus rendering the census of specific types occurring within the area inaccurate.

Otherwise we have nothing but commendation to bestow on the general mode of treatment of the subject, and it may be safely affirmed that the author has earned the gratitude of all naturalists on this side of the Atlantic by putting in a convenient and easily accessible form such a vast amount of information with regard to the mammalian fauna of an extremely interesting region. The illustrations (two of which are reproduced), it may be added, are, for the most part, beyond praise.

R. L.

\section{THE FISHERIES OF SCOTLAND.}

THE twenty-second annual report of the Fishery Board for Scotland, for the year 1903 , is issued in three parts as usual, the first dealing with the sea fisheries, the second with the salmon fisheries, and the third being concerned with marine research.

With regard to sea fisheries, tables are given showing the results of the trawl fishing and the line fishing. The number of steam trawlers has been increasing steadily for the last seven years, and rose from 109 in 1896 to 280 in 1903 . The average catch per vessel increased from $5030 \mathrm{cwt}$. to 5594 cwt., while the value of the catch per cwt. was practically the same in 1903 as it was in 1896 .

In the line fishing the number of steam liners increased from 39 vessels in 1898 to 91 vessels in 1903 , the number having varied somewhat in the intermediate years 23 vessels having been added in 1903. The total number of boats was slightly less than in 1898 , owing to a steady decrease in the number of sailing craft. The catch, since 
1898 , has steadily decreased from $1,050,000$ cwt. to 602,600 cwt., and the value per cwt. has slightly decreased. The reason given for the reduction in value of line-caught fish is that the trawlers have been landing large quantities of cod. Thus, in spite of the large increase in the number of steam liners, which are, of course, independent of wind in getting to the fishing grounds, the catch per boat fell from about 182 cwt. to about i2 I cwt.

It is interesting to note that for the herring fishing in the Buckie and Peterhead districts experiments have been made with sailing boats fitted with auxiliary steam power. The value of steam power is shown in another part of the report, where the catch of the Scotch boats (sailing craft) working from English ports during October and November is compared with that of the English boats, a large number of which are steamers. The Scotch boats caught more than $65^{\frac{1}{2}}$ per cent. of the total catch, but only got $4 t^{3}$ per cent. of the total value, the steamers always being able to make the market first.

The west coast mackerel fishing has shown great improvement, the catch in 1903 being 57 per cent. better than in 1902. The trade apparently only requires development, as "shoals of mackerel almost every year visit the coast."

In the report on salmon fisheries we learn that during the year $\mathrm{Mr}$. Calderwood, Inspector of Salmon Fisheries for Scotland, made inquiries as to the views of the various fishery boards with regard to the limitation of netting in narrow waters, this move being an outcome of the report of the Royal Commission on Salmon Fisheries.

Some of the boards have already taken steps to reduce the netting in their rivers. In the Annan all nets have been removed, while in the Spey only about three miles of water is now netted. In the Aberdeenshire Dee an association has, for about thirty years, annually bought off the nets on some sixteen miles of water, and now both upper and lower proprietors are seeking to secure the permanent removal of these nets.

While eleven of the boards consulted passed resolutions in favour of reducing the netting, six were unable to express an opinion, and only one, the Norrh Esk Board, passed a resolution against any such reduction. In Mr. Calderwood's words:-" The resalution was prepared and agreed to by the lower proprietors-who are in the majority-before the meeting took place, and was based upon the argument, supported by good evidence, that the present amount of netting in the district-which netting has been constant for a great number of years-has not produced a decline in the stock of fish. The question of improving the general interest of their whole district is complicated by other considerations which need not be referred to here."

One of the most important papers in this report is $\mathrm{Mr}$. Calderwood's contribution to the life-history of the salmon as observed by means of marking adult fish, the first part of which appeared in the report for 19or. Since then 62 additional re-captures of marked fish have been made, which, with those previously caught, gives a total of 252 re-captured fish. From this material, and also from other results obtained in Scotland, Ireland, and Norway, Mr. Calderwood has been able to draw some important conclusions. We now have evidence bearing out the commonly accepted view that the great majority of salmon after visiting the sea return to the river they left.

The marking experiments seem to show that grilse spend less time in fresh water than salmon, running up and down from the redds more quickly than the latter.

Another very interesting fact brought out is that a grilse kelt after running down to the sea may return within a few months as a summer salmon of about ro 1 b., or may remain in the sea until the following year, returning to the river as a spring salmon. This partly upsets the belief that spring salmon are old fish, for, although there is no doubt that old fish do run up in the spring, we now know that a fish of 18 or $20 \mathrm{lb}$. may only be five years old, according to $\mathrm{Mr}$. Calderwood, and on its second return from the sea.

There is evidence showing that some fish spawn in two successive seasons, and one case, No. 7298 , seems to suggest that the fish was spawning for the third year in succession.

There is a diagram, in which fish of various weights are considered as being of various ages, which shows the interesting facts observed as to the "dual migration" which exists, perhaps, in all stages of the salmon's life-history. NO, 1835 , VOL. 7 I ]
We know that all the fish of one hatching do not migrate to the sea at the same time. Some migrate at one year old, the great majority at two years, and some again at three years.

For the smolt to grilse stage Mr. Calderwood mentions three cases in which the smolts returned after a year and some months as grilse of $3 \frac{1}{2}, 3 \frac{1}{2}$, and $6 \frac{1}{2} \mathrm{lb}$. respectively, and says "we have no data to show any other seasonal migrations which may occur at this stage." We do not know whether the authority for the cases is untrustworthy, but we recollect records of smolts marked and released being re-caught after a few months as grilse up to $8 \mathrm{lb}$. weight. Such cases are mentioned by Fraser (" On the Salmon, \&c.," 1833, pp. 15, 16) and by Brown ("Stormontfield Experiments," p. 92), who says " the experiments here have shown ... that all the smolts of one year do not return the same year as grilse, the one half returning next spring and summer as small salmon."

$\mathrm{Mr}$. Calderwood shows that what he considers five-year-old fish do not increase in weight in the way that four-year-olds and six-year-olds do, and he suggests that this may represent the period in the life of the adult salmon when the reproductive function is at its best, and thus asserts itself at the expense of the body-growth.

Surely this classing of fish into ages by size can only be roughly correct at best. We do not yet know to what extent fish spawn annually or biennially, or whether a fish may rest several seasons after spawning. Yet if Mr. Calderwood's suggestion that the activity of the reproductive organs checks growth is sound, surely a fish spawning three years in succession-as No. 7298 suggests may happenwould be considerably smaller than a fish of the same age which spawned in alternate years or less often.

There are several other interesting papers in this part, but space precludes us from referring to them.

Part iii., scientific investigations, contains eight papers on various subjects connected with marine fisheries. Dr. $T$. Wemyss Fulton, the superintendent, gives an account of the trawling investigations, and in another paper continues the report of his investigations on the rate of growth of fishes. He also reports upon the operations of the Nigg Marine Hatchery, and has another paper entitled "Ichthyological Notes " on the various interesting species taken during the year.

An important paper is that by Dr. Williamson on the lifehistories of the edible crab and other decapod Crustacea. Dr. Williamson has discovered that the ova of the crab are not attached by mucilage to the long hairs of the spinnerets as was supposed, but that the eggs are actually pierced by the hairs, and are thus spitted in rows, the eggs not being attached to one another.

Dr. Thomas Scott contributes a paper on some rare and interesting marine Crustacea, and another upon some fish parasites new to the Scottish marine fauna.

The report is published at His Majesty's Stationery Office and can be obtained through any bookseller.

Frank Balfour Browne.

\section{PRIZE AWARDS OF THE PARIS ACADEMY OF SCIENCES.}

$\mathrm{A}^{\mathrm{T}}$ the annual meeting of the Academy of Sciences the list of prizes awarded for the year 1904 was announced as follows :-

Geometry.-The Bordin prize to M. Servant, for his memoir on the determination of surfaces applicable to the paraboloid of revolution which pass through a given contour; the Vaillant prize, divided between M. Emile Borel (300o francs) and M. Bricard (I000 francs); the Francœur prize to M. Emile Lemoine; and the Poncelet prize to M. Désiré André.

Mechanics.--A Montyon prize to M. Gustave Richard.

Navigation.-The extraordinary prize, of 6000 francs, divided in equal parts between M. Jacob (for his theoretical researches on the transmission of submarine explosions), M. Gayde (for a study of the resistance of hulls to submarine explosion), and M. La Porte (for hydrographic work on the coast of Brittany); the Plumey prize to M. Lucien Mottez, for important services to submarine navigation.

Astronomy. $\rightarrow$ The Pierre Guzman prize is not awarded; 